\title{
New Abrasive Materials and Their Influence on the Surface Quality of Bearing Steel After Grinding
}

\author{
Ondrej Jusko ${ }^{1}$ \\ ${ }^{1}$ CTU in Prague, Faculty of Mechanical Engineering, Technická 4, Prague, Czech Republic \\ Correspondence to: ondrej.jusko@fs.cvut.cz
}

\begin{abstract}
This paper focuses on the influence of various types of abrasive grains on cutting properties during the grinding process for bearing steel. In this experiment, not only conventional super-hard abrasive materials but also a new type of abrasive material were employed in grinding wheels. The measurement results were compared, and an evaluation was made of the cutting properties of the new abrasive material. The options were then evaluated for their practical applicability. The measurement results indicated that a grinding wheel with Abral and SG grains is the most suitable for grinding hardened bearing steel in order to achieve the best roughness and geometrical accuracy.
\end{abstract}

Keywords: grinding, bearing steel, abrasive material, roughness, geometric accuracy.

\section{Introduction}

Research and development in the area of grinding wheels is a basic aspect of grinding technology. Three groups of abrasive materials are employed in grinding wheels. The first group consists of conventional grinding wheels made of $\mathrm{Al}_{2} \mathrm{O}_{3}$. Super-hard grinding wheel on the basis of $\mathrm{CBN}$ and diamond form the second group. It is less expensive to apply grinding wheels based on $\mathrm{Al}_{2} \mathrm{O}_{3}$, but there is a risk of thermal damage to the working surface. When we apply CBN and diamond-based grinding wheels, we can produce high quality surfaces, but this is an expensive method. This situation provided the motivation to seek a new direction in the development of grinding wheels, and to investigate a type of grinding wheel with an innovative abrasive material. This third group of abrasive materials consists of grinding wheels with SG and Abral grains.

\section{Experimental details}

The bearing steel was ground using the plunge-cut grinding method on a cylindrical grinding machine. We used rings of 14109.6 bearing steel as samples. The surface roughness was measured using the Talysurf 6 laboratory type contact profilomer, to measure the surface with the profile method with progressive transformation of the information on the profile throughout the mechanic shift of the point. The Talyrond 30 device, which uses the rotary table principle, was used for measuring the roundness. The parameters for the experimental measurements were: - speed of the wheel $v_{c}=45 \mathrm{~m} / \mathrm{s}$
- speed of the workpiece: $v_{P}=30 \mathrm{~m} / \mathrm{min}$

- grinding cycle:

1st phase: $a p=0.03 \mathrm{~mm}, v f_{r}=0.52 \mathrm{~mm} / \mathrm{min}$

2nd phase:

$a p_{1}=0.02 \mathrm{~mm}, v f_{r 1}=0.52 \mathrm{~mm} / \mathrm{min}$,

$a p_{2}=0.01 \mathrm{~mm}, v f_{r 2}=0.26 \mathrm{~mm} / \mathrm{min}$

3rd phase:

$a p_{1}=0.02 \mathrm{~mm}, v f_{r 1}=0.52 \mathrm{~mm} / \mathrm{min}$,

$a p_{2}=0.005 \mathrm{~mm}, v f_{r 2}=0.26 \mathrm{~mm} / \mathrm{min}$,

$a p_{3}=0.005 \mathrm{~mm}, v f_{r 3}=0.11 \mathrm{~mm} / \mathrm{min}$

- grinding tool:

$\mathrm{Al}_{2} \mathrm{O}_{3}$ - white corundum (aluminium oxide), a conventional material. The results were used for comparative purposes. A 99A 60J 9V grinding wheel was used.

CBN - cubic boron nitride is another very hard material. Its regular grain and firm bond make it suitable for grinding hard surfaces. A B-VII B64 K75 grinding wheel was used.

SG (Seeded Gel) — is a ceramic aluminium oxide manufactured by a sintering process. Each abrasive frit consists of sub-micron size particles which are separated from the grit under the grinding force. This keeps SG sharper than conventional abrasives, which can be dulled when flats are worn on the working points. An AG 92/99 $80 \mathrm{Hs}(\mathrm{J})$ 9V grinding wheel was used.

Abral - is a crystalline mixture of $\mathrm{Al}_{2} \mathrm{O}_{3}$ and $\mathrm{AlON}$. Abral is produced by fusing aluminium oxide with AlON, followed by slow solidification. The material is created by natural crystallization and the monocrystalline mixture is not disrupted by crushing. The crystalline mixture has a firm structure and a firm lattice. For this reason, its surface is more resilient 
and harder than a regular corundum surface. An AG 92/99 $80 \mathrm{Hs}(\mathrm{J})$ 9V C45 grinding wheel was chosen for this experiment.

\section{Results}

\subsection{Surface Roughness}

The results of the study show, that the most appropriate material is the grinding wheel with SG and Abral grains. This conclusion is based on the roughness criteria that were achieved. In the grinding cycle with one or two phases, Abral seems to be a better grain option for the roughness criterion. In the threephases grinding cycle, the $\mathrm{Ra}$ value results are almost identical for the abrasive materials. However, the SG material produced better profile results.

The second grains roughness group consists of $\mathrm{Al}_{2} \mathrm{O}_{3}$ and $\mathrm{CBN}$. The CBN wheel is made of sharper grains and the instrument produces better thermal conductivity, i.e. its surface is not so heavily thermally loaded. This results in a sharper surface than that of $\mathrm{Al}_{2} \mathrm{O}_{3}$ wheel, the grains of which have a bigger radius. This also affected the surface roughness measurement after the hardened bearing steel had been ground. An interesting finding was that when the cut was applied to this abrasive material, the best roughness results were obtained when the speed of the cross feed was highest and when the depth of the cut was greatest.

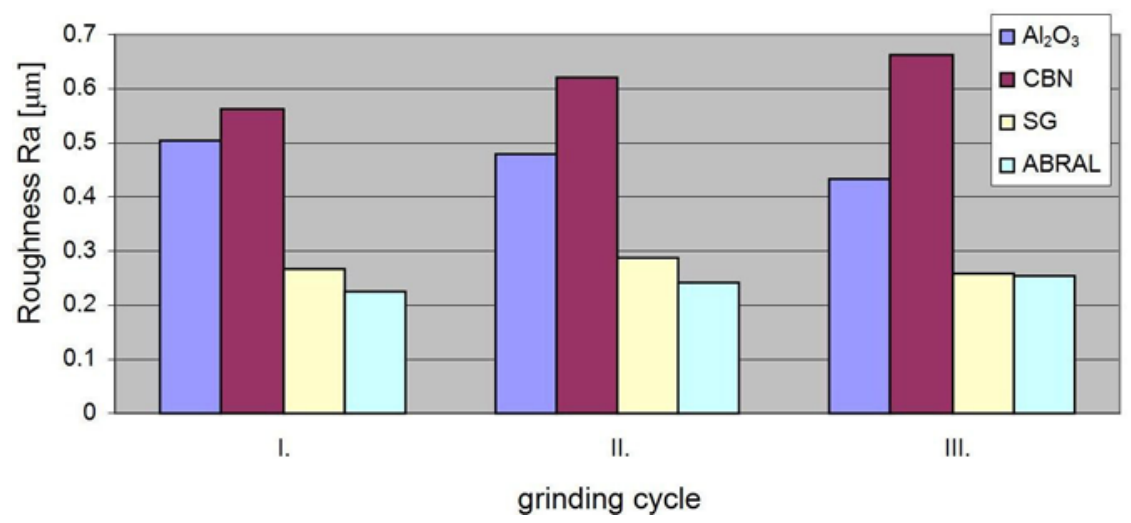

Figure 1: Influence of the grinding cycle on the surface's roughness Ra

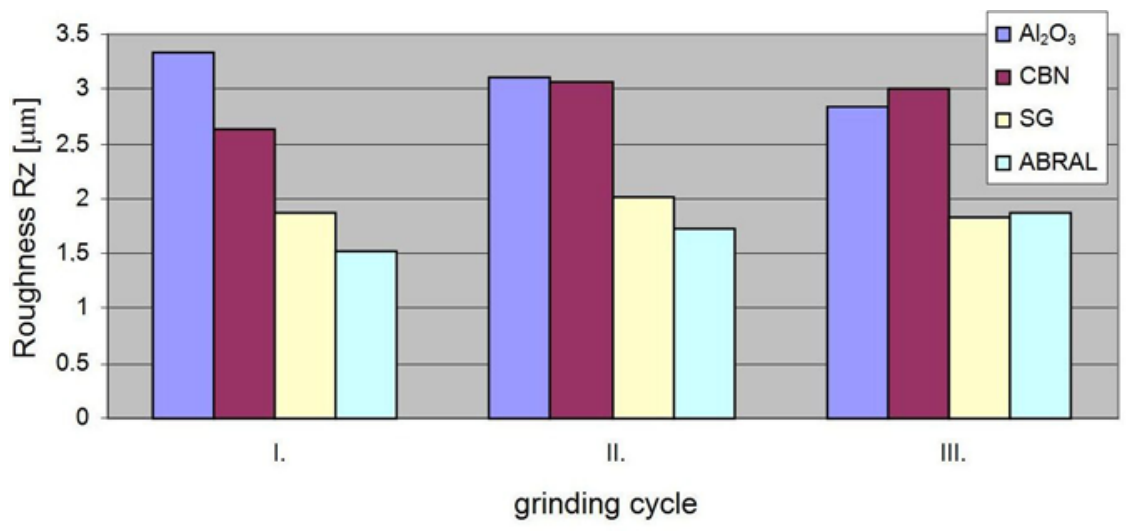

Figure 2: Influence of the grinding cycle on the surface's roughness $\mathrm{Rz}$

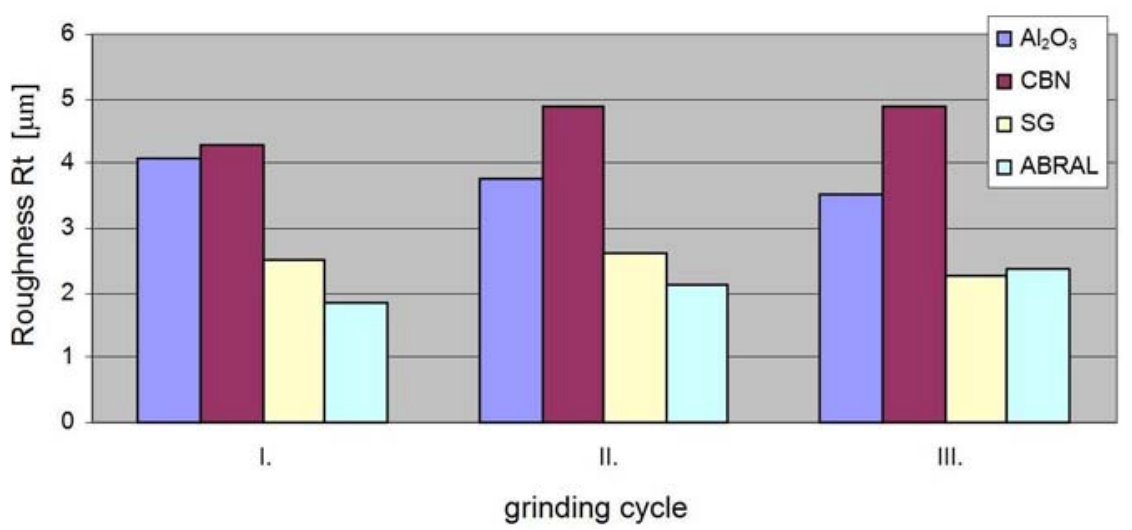

Figure 3: Influence of the grinding cycle on the surface's roughness Rt 


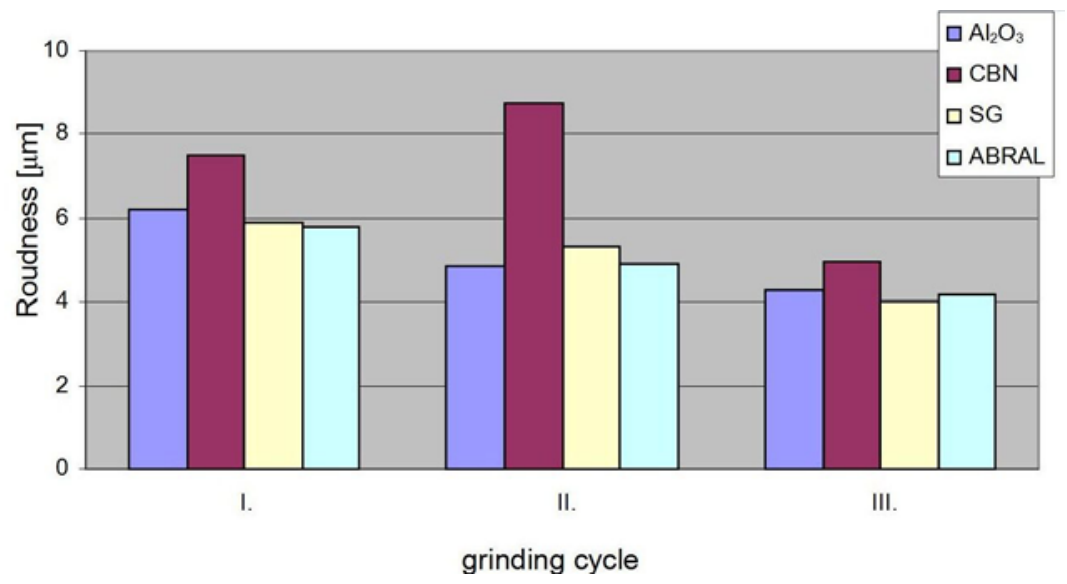

Figure 4: Influence of the grinding cycle on the out-of-roundness

\subsection{Geometric accuracy}

A comparison of the measurements shows, that the CBN wheel has quite a big tendency to deviate from roundness. This deviation may originate from the production of the grinding wheels, which have thin layer of the abrasive material with the binder on their metallic surface. The production process involves a certain axis deviation of the metallic body and deviation of the axis of the thin abrasive material layer. This eccentricity creates a change in the depth of the cut-off layer, i.e. in the frequency, due to the high speed of the wheel.

Figure 4 shows, that when a conventional wheel and an innovative type of abrasive grinding wheel are used with decreasing cut depth, thus reducing the radial feed rate, the roundness deviation also decreases. The roundness values that are achieved are comparable with the values for these abrasive materials. The lowest roundness value is for the Abral grinding wheel in the $1^{\text {st }}$ and $2^{\text {nd }}$ grinding cycle and for the SG grinding wheel in the $3^{\text {rd }}$ grinding cycle.

\section{Conclusion}

Our experiment has shown that the least appropriate material for the grinding wheel $\mathrm{s}$ for the cutting 14109.6 bearing steel is $\mathrm{CBN}$ with $\mathrm{Al}_{2} \mathrm{O}_{3}$ grains. Abral and SG grinding wheels are more suitable, due to the high durability of the CBN grain layer on the perimeter of the wheel, despite the high cost and the high demand on the accuracy of the ring when mounting the bearing. A comparison of the two inno- vative abrasive materials shows that the performance of Abral is slightly superior.

There are several unanswered questions that require further research and development on the influence of the abrasive material in relation to the formation of the new surfaces in the cutting process. A possible application would be for the measuring the temperature in the contact spot between the abrasive tool and the workpiece, and consequently, its influence in relation to the production and the distribution of the residual tension in the superficial bearing steel after grinding.

\section{References}

[1] Gašparek, J.: Dokončovacie spôsoby obrábania. Bratislava: ALFA, 1979. ISBN 63-009-80.

[2] Jusko, O.: Vplyv nových brúsiacich materiálov na obrábací proces. Dizertačná práca, Praha : České vysoké učení technické v Praze, Fakulta strojní, 2011.

[3] Mádl, J., Holešovský, F.: Integrita obrobených povrchů z hlediska funkčních vlastností. Ústí nad Labem : FKK Company, 2008. ISBN 978-80-7414-092-2.

[4] Marinescu, I., Hitchiner, M., Rowe, B.: Handbook of Machining with Grinding Wheels. New York : CRC Press, 2007. ISBN 1-57444-671-1.

[5] Ondirková, J., Neslušan, M.: Analýza reznosti SG brúsnych kotúčov pri brúsení 14209.4 . In Valivé ložiská a strojárska technológia 2002, Súlov : Žilinská univerzita, 2002. 